\title{
ENERGY EFFICIENCY FOR SUSTAINABLE REUSE OF PUBLIC HERITAGE BUILDINGS: THE CASE FOR RESEARCH
}

\author{
O. K. AKANDE, D. ODELEYE \& A. CODAY \\ Department of Engineering \& the Built Environment, Anglia Ruskin University, Chelmsford, UK.
}

\begin{abstract}
There is a wide consensus that buildings, as major energy consumers and sources of greenhouse gas emissions must play an important role in mitigating climate change. This has led to increasing concern and greater demand to improve energy efficiency in buildings. Although, there has been increased efforts to reduce energy consumption from existing building stock; the heritage sector still needs to accelerate its efforts to improve energy efficiency and reduction in greenhouse gas emissions. Presently, much concentration has been on improving the energy efficiency of heritage buildings in the domestic sector while, the non-domestic sector has only received little attention. In particular, studies focusing on reuse and adaptation of heritage buildings for public use to achieve more efficient use of energy are urgently required. The main focus of this paper is the need for research into sustainable reuse of public heritage buildings with reference to maximising energy efficiency in the process of considering their conversion to other uses. The paper presents part of a broader on-going research with the aim to investigate problems associated with maximising energy efficiency in reuse and conversion of public heritage buildings. It identifies the ability of heritage buildings to play a role in global reduction of energy use and $\mathrm{CO}_{2}$ emission whilst maintaining its unique characteristics. Issues and challenges associated to improving energy efficiency in heritage building conversion projects were discussed. Holistic approach through identification of various options and innovative techniques for their sustainable reuse were suggested. The paper concluded that in spite of the exemption of listed buildings from energy performance requirements, these buildings can still accommodate some energy efficiency improvements. However, further studies to identify the most suitable options for long term sustainability is required if the goal to reduce greenhouse gas emissions by $80 \%$ by 2050 is to be achieved.

Keywords: Adaptation, conservation, conversion, refurbishment, energy efficiency, heritage buildings, renewable technology, reuse, sustainability.
\end{abstract}

\section{INTRODUCTION}

Worldwide attention is currently focused on the widespread impacts of global climate change and the issues of greenhouse gas emissions. A big and well documented global opportunity exists to save money and reduce greenhouse gas emission by using energy more efficiently. Buildings represent between $40 \%$ and $45 \%$ [1] of many European countries' energy needs. The UK has significant carbon reduction targets over the coming decades, and reducing energy use is one of the main ways of achieving this. The energy efficiency of buildings has been targeted by the UK government in its drive to reduce greenhouse gas emissions by at least $80 \%$ by 2050 .

Numerous studies indicate that buildings' energy usage can be cost-effectively reduced by some 20\%-50\% [2] and, depending on how 2050 emissions reduction targets are met, it is likely that many countries will have to go significantly further [2]. According to estimates by the Carbon Trust, nondomestic buildings in UK account for approximately $20 \%$ of all carbon emissions [3]. Many of the existing older buildings have been described to be operating very inefficiently because their energy consumption is high [4]. Therefore, they are increasingly recognised as one of the key barriers to major reductions in $\mathrm{CO}_{2}$ emissions. This comes most sharply in focus where buildings have heritage value.

Improving the energy efficiency of these existing building stocks will not only generate energy savings with attractive levels of return on investment, it can also improve a nation's energy security, create jobs and make buildings more liveable. Studies show that $\$ 60-300$ billion could be invested 
globally each year to fully capture the cost-effective energy efficiency opportunity [5]. Estimates vary widely because of different baselines and assumptions, but all agree that the opportunity to cost-effectively improve energy efficiency is enormous. The policies about energy efficiency date back to the oil crisis of the 1970s. However, it is only in recent years that it has gained the full attention of Governments.

Presently, the global financial crisis has led to an unparalleled focus on efficiency of measures to reduce energy consumption and emissions in buildings. Hence, the case for this ongoing research on maximising energy efficiency in conversion projects involving heritage buildings is the subject of this paper. The paper presents part of a broader on-going research whose aims are to investigate problems associated with maximising energy efficiency in reuse and conversion of public heritage buildings. It identifies the ability of heritage buildings to play a role in global reduction of energy use and $\mathrm{CO}_{2}$ emission whilst maintaining its unique characteristics.

\section{REUSE OF EXISTING BUILDINGS: A SUSTAINABLE OPTION}

Generally, buildings inevitably decline in utility or usefulness over a period of time, and as a result, interventions will be required in order to ensure they retain their utility. The retention and reuse of older buildings can play a pivotal role in the sustainable development of a city. The interventions could come in the form of refurbishments, renovations, retrofits and adaptive reuse or conversion of buildings from one use to another. Steemers [6-9] opined that some form of adaptation may be able to reduce climate change impacts on the built environment. However, this has not been given as much attention as new buildings where there is much work on low and even zero energy buildings.

In most European cities there is a vast stock of existing buildings, many of which are getting to the end of their useful life. Several authors have suggested that the adaptation of these buildings could be an effective strategy to improve their sustainability [10-14]. This notion is supported by Rovers [15] with emphasis that the existing buildings stock has the greatest potential to lower the environmental load in a significant way. While demolition appears to be an option, however, replacing an existing building with a new one requires a considerable investment of 'embodied' energy in materials, transport and construction [16]. Therefore, when a building is demolished, its embodied energy is lost.

Jackson [17] further emphasised that if a replacement building is energy efficient, it will be decades before savings in operating energy can outweigh the embodied energy of the old building. On the other hand, if the structure and envelope of a building is reused, half of its embodied energy is conserved (see Fig. 1). Hence, the alternative of reuse is starting to be seen as a more environmentally friendly and sustainable option particularly for reasons of architectural and historic value, material use, neighbourhood disruption, waste disposal, etc. In global environmental terms, the balance of advantage of refurbishment strongly favours the retention of existing building stock with its elements

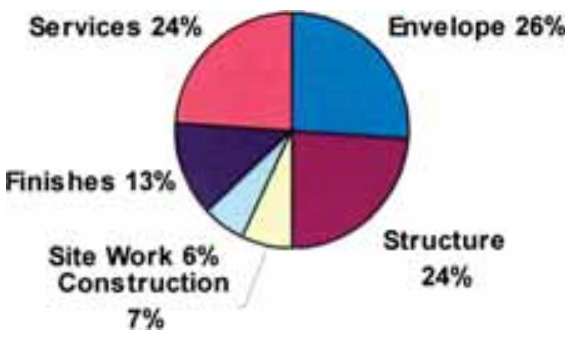

Figure 1: Average embodied energy. Source: Cole and Kernan [20]. 
(i.e. including construction) particularly when performance in terms of energy consumption in use can be improved. This act of retaining existing elements of construction in old buildings and seeking to enhance their thermal performance, rather than replacing them, has become part of heritage conservation principle in line with sustainable development $[18,19]$.

However, many old buildings use large amounts of energy and also have poor internal conditions for occupants and generally do not meet current requirements or expectations. Their common environmental problems also include: high heating demand, poor lighting, poor ventilation, solar penetration and glare, poor control of heating and cooling, etc.

\subsection{The need for energy efficiency in reuse of heritage buildings}

Many previous studies have concluded that it has become necessary to work more efficiently with the existing building stock rather than simply opt for demolition and redevelopment [21, 22]. Hence, more studies are increasingly focusing on the adaptation of existing buildings to achieve more efficient use of resources, reduce energy consumption and greenhouse gas emissions [23, 24]. In recent years, redundant heritage buildings have been converted to other functions either for private or for public use. Therefore, reuse of historic buildings can be considered as a sustainable practice of utilising an already existing resource. However, their heating and cooling to current-day comfort standards has been a real source of energy consumption while, at the same time, their conservation are faced with many challenges of meeting global challenge of coping with climate change and maximise energy efficiency without sacrificing their special character.

The Directive on the Energy Performance of Buildings [25] and its recast [26] introduce incentives and obligations for public and private sector to save energy and reduce running costs. However, historic buildings are excluded from these commitments as stated in the recast: 'Article 4 - Setting of energy performance requirements: Member States may decide not to set or apply the requirements referred to in paragraph 1 for the following categories of buildings: buildings and monuments officially protected as part of a designated environment or because of their special architectural or historic merit, where compliance with the requirements would unacceptably alter their character or appearance;' [26].

Although the actual building regulation exempts listed buildings from energy performance improvements, however, many existing public heritage building stock still remains as energy consumer [27] while energy savings in historic buildings can go hand in hand with heritage conservation. A typical example is shown by an infrared image of heat loss of the Houses of Parliament in Fig. 2. It is therefore important to take advantage of the opportunities to improve the energy efficiency of these buildings when they are been refurbished or adapted for a change of use. Hence, as indicated by Kikira and Gigliarelli [28] the enrichment of knowledge and scientific research into the sustainability and energy efficiency in reuse of historic buildings is imperative, considering their vast potential all over Europe.

\subsection{The emerging area of concern}

Presently there are many existing buildings that are heritage registered in UK. In 2006, there were nearly 22.5 million dwellings in England [30]. Although the exact numbers that are listed are not yet known due to the increasing number in listing, however, English Heritage's figures on the proportion of listed buildings that are domestic are $37.8 \%$ and applying that to the estimated 500,000 listed individual buildings, it can be inferred that listed building represent approximately $1 \%$ of the total number of dwellings [30]. The Institute of Historic Building Conservation estimate of the number of 


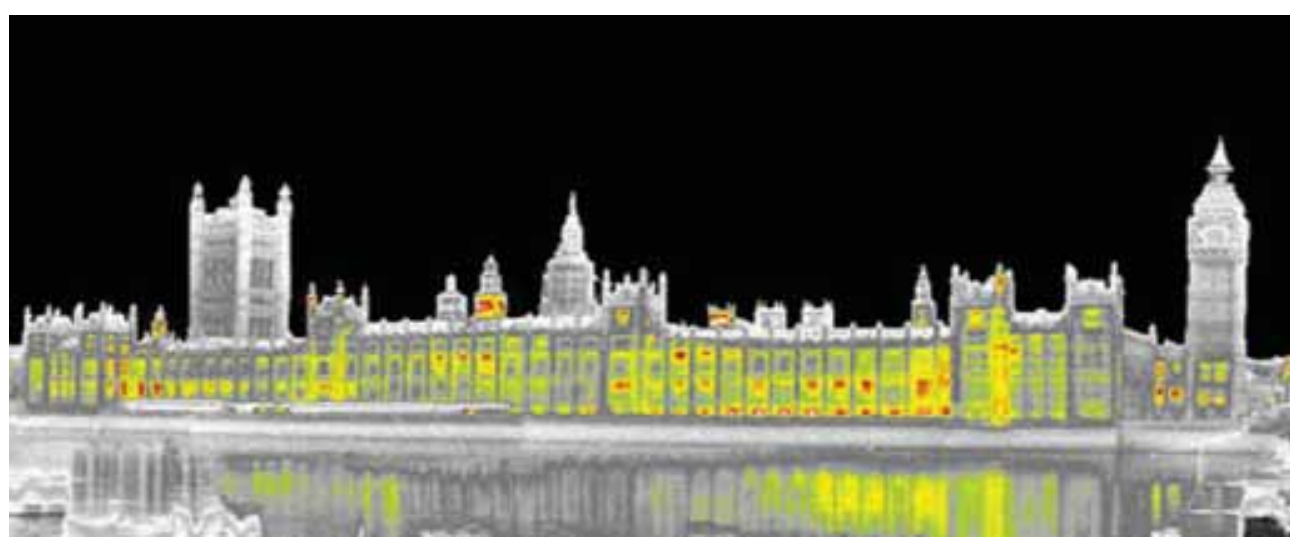

Figure 2: An infrared image of heat loss of the Houses of Parliament. Source: ThermalCities [29].

listed buildings put this figure at $1.5 \%$. Assuming the same rate of carbon emissions for listed and unlisted building, it can be inferred from this that the contribution of designated historic buildings to carbon dioxide emissions must be around $0.25 \%$ of all carbon dioxide emissions [30].

Although buildings of cultural heritage significance are quantitatively a small proportion of the building stock, they are, nevertheless, significant in terms of their contribution to reducing greenhouse gas emissions through measures to improve their energy efficiency and the broader aims of achieving sustainable development [31]. An extensive review of scholarly literature on adaptive reuse of older (including heritage) buildings from the 1970s onwards shows that the driving force behind the reuse of these buildings was functional, technical and economical [32-36]. However there is little or not much emphasis on their energy upgrades. At present, public historic and traditionally-built structures are considered for other uses; this creates an opportunity for them to play a role in reducing their carbon emissions.

Traditional buildings are generally regarded as those structures built before 1919. They were built from a limited palette of largely natural materials that were more or less vapour permeable. These buildings are commonly perceived as energy inefficient $[37,38]$ with a high proportion of them in use for housing where pressure for energy efficiency improvement is high. Although, in many projects relating to refurbishment of heritage buildings especially in domestic sector, different measures have been applied in terms of energy efficiency to get a feel for what is technically and technologically feasible. While these interventions require a greater attention in conversion of public heritage buildings, the question of how it can be effectively done and to what standard in conversion projects is an emerging area of concern.

\subsection{Potentials of available technologies to improve energy efficiency of heritage buildings}

The technologies that are easy to implement and indispensable for successful refurbishment projects are those that start with energy-related upgrades. Since the first energy crisis in 1973, it has become clear that one of the key steps to security of energy supply is energy efficiency, on both the supply and demand sides [38, 39]. In this regard, a wide range of literature [40] has viewed energy efficiency as a generous and relatively inexpensive resource of energy. Levine et al. [41] concluded that buildings house a significant amount of energy efficiency potential, which can be realised using existing energy efficiency technologies. Hence, reuse of historic buildings can and should be 
undertaken to extend building life and better capture the energy savings available through newer technologies.

Currently, energy efficiency technologies and their innovative application that have been developed around the globe could be divided between the design phase and the operational phase. Although in the design phase the possibilities are wider, many times only after the building awareness on efficiency is raised and better use of resources targeted. However, it is possible to incorporate energy efficiency measures and better use of the renewable resources in buildings in their operational phase or when they are converted to other uses. A typical example and trend of these possibilities was demonstrated in the refurbishment of the 140 year-old Renewable Energy House (REH) Brussels.

The Renewable Energy House was refurbished to minimise energy consumption and to explore different methods for integrating renewable energy technologies, making it a $100 \%$ renewable energy building. Figures 3 and 4 show their façades before and after refurbishment. The concept was designed on the one hand to reduce the annual energy consumption for heating, ventilation and air conditioning by $50 \%$ compared to a reference building and, on the other hand, to cover all the needs for heating and cooling by $100 \%$ renewable energy sources. The building was equipped with a series of energy efficiency technologies (insulation of the façades and roof, highly efficient double glazing, high-efficiency lamps, ventilation with heat recovery). 100\% of the building's heating and cooling demands were also provided by renewable energy sources (biomass wood pellets, geothermal heating, solar thermal heating and absorption cooling). In addition to these measures, the building features the latest photovoltaic (PV) technologies (modules, thinfilm, semi-transparent) for the production of electricity. It was observed that in the REH's refurbishment project, all measures implemented contributed to reducing the energy consumption of the building in addition to the benefit of increasing the comfort for its tenants.

The successful implementation of these measures could therefore be commended as it demonstrates that it is not only possible to significantly reduce a building's energy needs, but also to deal with the multiple constraints associated with heritage building whilst offering a $100 \%$ renewable energy supply. This could be argued against the notion that it is difficult for heritage buildings to be adapted to integrate energy efficiency measures with combination of available top-of-the-art renewable energy technologies for fear of changing their nature and appearance.

Although a certain degree of caution needs to be maintained when making plans for reuse of heritage buildings, for reasons of the fact that what is obtainable in a particular building cannot be generalised for all buildings as each building needs to be treated on case by case basis.
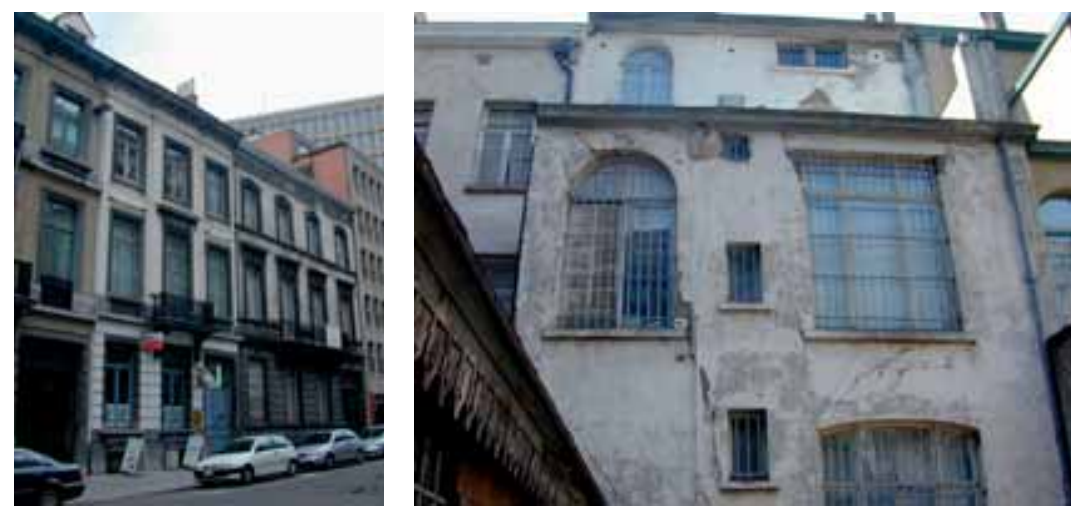

Figure 3: Front and back façade of the renewable energy house, Brussels, before refurbishment. Source: Adapted from New4Old [27]. 


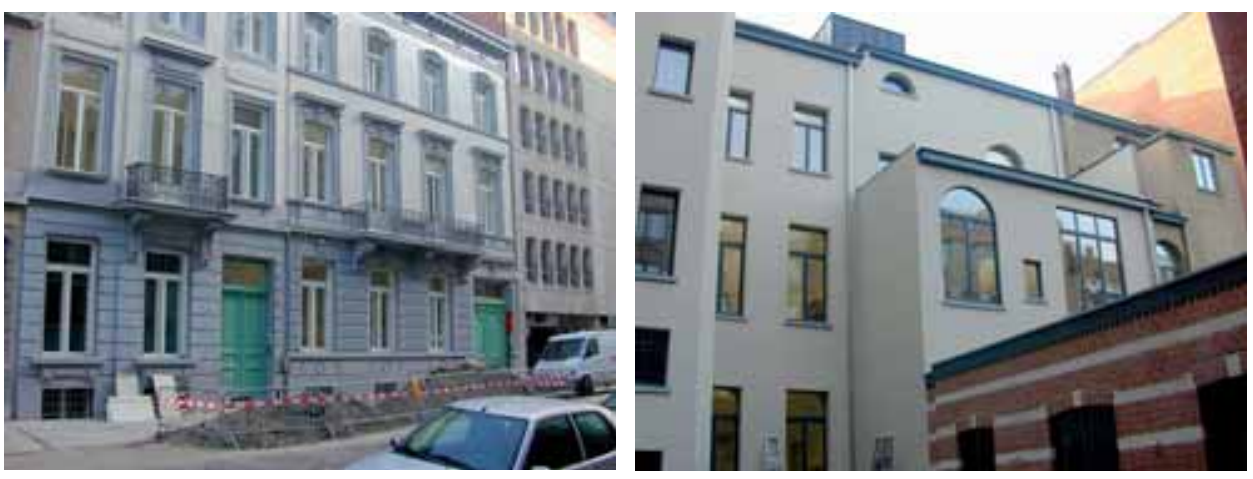

Figure 4: Front and back façade of the renewable energy house, Brussels, after refurbishment. Source: Adapted from New4Old [27].

More often, the decision to reuse public heritage buildings are mostly based on finding suitable and sustainable economic use while, questions of energy consumption in these buildings are generally seen as secondary. Meanwhile, good technologies that can meet reduction of energy consumption in these buildings are currently available. The main obstacle to their implementation has been a general lack of their knowledgeable application. In demonstrating one of the good practices of these technologies, Zidar and Hrs Borković [42] provided evidence that highest savings in energy consumption can be achieved in all types of buildings by integrating energy efficiency measures in a harmonious energy system.

They argued that total energy savings can be even higher when using passive house. This argument was based on the goal of a project to conserve the existing and to rehabilitate with high energy efficiency a pre-1900 building formerly used for industrial production for 100-years old. The building was on one hand professionally and historically revitalised while on the other hand was also rehabilitated with high efficient resources from renewable energy. The building was refurbished to accommodate office building in Wels, standard principles in Austria shows renovation of ' $10+$ factor', achieving energy autonomous building, reducing energy consumption by $90 \%$ and mitigating $\mathrm{CO}_{2}$ emission by $95 \%$.

High efficient vacuum insulation was applied on a part of the façade for rehabilitation of thermal bridges while the rest of the envelope was thermally insulated on the inside of the wall preserving existing envelope appearance. This resulted to the development of a durable façade with standard passive house. In improving the energy efficiency of the building, heat retention of the fabric was the first step. Therefore reducing energy demand of the building enabled the use of efficient and innovative systems with renewable energy sources, reducing energy and management costs, improving indoor comfort and minimising environment impact [42].

Heat energy was generated from using flat ground source heat pump with application of additional passive cooling technique, while electricity was generated by photovoltaic modules. The use of day lighting technique was also explored to reduce the use of artificial lighting. While the above energy efficiency interventions could be considered as a good practice to refurbishing old buildings, it may not always be appropriate to all historic buildings. In the UK, most historic buildings are listed and have solid walls. Therefore, great care is needed whenever they are to be considered for reuse or refurbishment. However, in cases where there are cavity walls and timber, i.e. framed construction, these measures could be a viable option. 


\subsection{Energy efficiency and building conservation: synergies of possibilities}

In listed historic buildings, usually it is the fabric-related demand-reducing measures that create the greatest conflicts between heritage and energy conservation. For example, the historic, aesthetic and cultural interest of the external and internal surfaces of a wall, or the detailing around the windows, may make wall insulation completely impossible. And where it is aesthetically acceptable, it may introduce technical risks, often moisture-related, that preclude this measure. However, in the same building it might be relatively easy, cost-effective and technically acceptable to install a more efficient boiler, controls and electrical equipment and as well change to lower-carbon fuel supplies.

Renewable energy sources and micro generation could also play a major role as supplementary to other energy saving measures. These are addressed mostly by photovoltaic panels, biomass and solar thermal systems. In most countries, photovoltaic panels could be installed onto historic buildings only if out of view and if they can be removed with little long term impact to the building. A case exemplar building that demonstrates this is a nationally recognised heritage building of Grade I listed status of St Michael and All Angels Church, Withington, Gloucestershire, UK. As with most listed churches, many aspects of this heritage building are of significance with special elements. Most listed churches and other grade I listed buildings consist of external features of decorative façades, windows, doors internal features of interest (i.e. decorated and painted surfaces) with details such as mouldings, stucco-work, wall and ceiling decorations as well as internal spaces [43]. These pose difficulties and limitations to application of many energy efficiency measures (e.g. insulation) because they serve as the most important features of the building which are valuable, respected and conserved.

Due to the elements that make up the special character and interest of the building, a combination of solar photovoltaic (PV) for the electricity and a biomass boiler for the heat was selected as the most appropriate renewable combination to meet the buildings energy demand. Because the building has an east/west orientation of the aisle with one side of the nave pitched roof at 30 degrees facing south and entirely hidden by a parapet wall around all sides, it was possible to install a $3.24 \mathrm{kWp}$ system of 24 solar PV panels covering $24.05 \mathrm{~m}^{2}$. The characteristics of the roof make the installation invisible and less visually intrusive and acceptable for the listed building.

Before the intervention, the initial oil usage was 4,000 1/year with carbon emissions of 12,116 $\mathrm{kgCO}_{2} \mathrm{e} /$ year. However, with the change of fuel to the use of biomass pellets which was estimated to be around 2 tonnes (i.e. approximately $0.052 \mathrm{kgCO}_{2} \mathrm{e} / \mathrm{year}$ ), the biomass installation could now save over 12 tonnes in carbon emissions. This is a significant contribution to carbon emission reduction from listed heritage building. It could therefore be concluded from heritage conservation perspective, that possibilities to improve energy performance with reduction of carbon dioxide emissions could blend and not conflict with building conservation. This brings to the fore the importance of considering possible impact of different energy efficiency measures in any heritage projects.

\subsection{Impact of energy improvements measures on heritage buildings}

Building reuse and retrofits of existing buildings are important strategies for reducing carbon emissions. However, it is impossible to prescribe a single package of measures that would be applicable to all existing listed buildings. The most suitable and cost-effective options will depend, to a large degree, on the opportunities arising from the proposed reuse and the form of construction (i.e. the fabric of the building). Table 1 shows the possible impact of different improvements of energy efficiency measures in conversion projects. 
Table 1: The impact of different energy improvements.

\begin{tabular}{lll}
\hline Measures & Energy saving & Impact on appearance \\
\hline Loft insulation & High & Low \\
Ground floor insulation & High & Low \\
Central heating improvements & High & Low \\
Draught proofing & High & Low \\
Energy efficient lighting & Moderate & Low \\
Internal wall insulation & High & Moderate \\
External wall insulation & High & Moderate/High \\
Window improvements & High & Moderate/High \\
Solar thermal hot water & High & Moderate/High* \\
Photovoltaic panels & Moderate & Moderate/High* \\
\hline
\end{tabular}

*The aesthetic impact of renewable energy technology that may not be suitable for some buildings which are listed or in a conservation area based on the nature of their fabric.

Source: Eco-refurbishment and the historic environment [44].

The aesthetic impact of renewable energy technology may vary considerably with location and building, and these measures may not be suitable for some buildings which are listed or in a conservation area depending on the nature of their fabric. However, if a measure is sensitively sited the aesthetic impact can be reduced from high to moderate, depending on the building, its orientation and location and other factors. Though all heritage buildings may never reach the energy efficiency standards of a new build because of certain conservation principles, there are still significant energy savings that can be achieved in many others.

\subsection{Energy efficiency improvement of existing heritage buildings: conflicts and constraints}

The challenge for refurbishing and upgrading existing stock is immense - refurbishment projects obviously need to upgrade the structure, the fabric and the building's services whilst complying with standards and legislation. Among other factors, they should also address the potential effects of climate change, have minimal environmental impact, conserve heritage buildings, provide more safe and secure and comfortable internal environments as well as produce spaces that are adaptable for change of use. However, interventions involving energy efficiency in heritage buildings require a holistic study in order to address potential risks such as: moisture and condensation occurrence, chemical incompatibility of old with new construction materials, failures due to limited construction knowledge on restoration applications with sustainable technologies [28]. Some of the constraints that may result to difficulties are shown in Fig. 5 and discussed below.

\subsubsection{Modification of building structure}

Alteration for re-use facilitates change with associated difficulties and risks to heritage buildings. Alteration for re-use is part of the conservation process of managing change to a culturally significant building which will sustain its heritage values whilst engaging in opportunities to enhance, develop and introduce energy efficiency improvement. However, according to Oxley Conservation [45], changes can interfere with a buildings breathing performance. It can mean loss of character and 
a spoiling of appearance and or loss of historic fabric. Therefore, it is important to remember first to identify the significance of the building, which requires an understanding of the nature of the structure, who values it and why, how do the values relate to the fabric and what is the importance of these values relevant to the reuse advantages.

This understanding and articulating the values and significance of building for reuse is necessary to make informed decisions about the energy efficiency improvements to be carried out. Without their due consideration, all the good intentions of reuse initiative will eventually compromise the cultural significance for future generations to come. It is therefore paramount to understand the history of construction, modification and use, cultural significance and protected status. It is also important to get grips with the performance, intended performance and changes in intended performance along with performance in use [46].

\subsubsection{Thermal bridges and wall insulation}

According to Oxley Conservation [45], most traditional buildings are built with stone, soft bricks, timber and earth using earth or lime based mortars and renders. These materials allow moisture to be absorbed and then to readily evaporate, allowing the building to 'breathe'. The levels of dampness are 'controlled' by the ready evaporation of moisture. Traditional buildings create particular challenges when considering them for energy efficiency measures. It is acknowledged in much of the literature that the behaviour of moisture within traditional constructions is likely to be different from that within a modern building, and that the insulation of these buildings alters moisture balances [47].

This poses much greater risk of condensation occurring in heritage buildings as a result of air leakage which transports water vapour through gaps, joints and cracks in the building fabric. In worst cases, when the walls become cold and wet it can cause a rise in U-values and a reduction in thermal performance. English Heritage [48] guidelines on adding insulation into existing permeable construction states that insulation which has hygroscopic properties should be used as this offers a beneficial 'buffering' effect during fluctuations in temperature and vapour pressure, thus reducing the risk of surface and interstitial condensation occurring.

However, high levels of humidity can still pose difficulties even when the insulation is hygroscopic. Insulation materials with low permeability are not entirely incompatible with older construction but careful thought needs to be given to reducing levels of water vapour moving through such construction either by means of ventilated cavities or through vapour control layers [48]. The movement of water vapour through parts of the construction is a key issue when considering thermal upgrading of heritage buildings. Many other factors need to be considered to arrive at an optimum solution such as heating regimes, the orientation and exposure of the particular building.

With regard to internal insulation in reducing heat loss due to thermal bridging around windows, doors, floors, party and partition walls, roof-wall junctions and lintels, Andersson [49] and Schnieder [50] identifies limits to the effectiveness of internal insulation. Schnieder [50] observations showed that there is decreasing marginal returns on the thickness of insulation to walls due to unavoidable thermal bridges. Andersson [49] however found that where little or no insulation is possible on certain thermal bridges, such as window reveals, the possible insulation values of the whole wall became reduced considerably. In a study relating to the difficulty of dealing with thermal bridging when applying external wall insulation, Hooper et al. [51] also highlighted numerous examples of thermal bridging in houses fitted with external wall insulation.

\subsubsection{Air tightness (inadequate ventilation) and risks of health}

Mechanical ventilation and heat recovery systems (MVHR) are sometimes specified as part of energy-efficient refurbishments; however, such systems rely on buildings being well-sealed to 
function effectively. This could pose serious danger of creating long-term health problems for heritage buildings and the occupants. Based on the nature of their construction, historic and traditional buildings need ventilation to preserve the fabric, to maximise evaporation of moisture and maintain an acceptable equilibrium. However, STBA [47] has argued that suitable levels of ventilation for traditional buildings constructed of moisture-active (i.e. 'breathable') materials are yet unknown.

Oxley conservation [45] stated that the provision of excessive or poorly thought out draught proofing to achieve an arbitrary level of air tightness could lead to mould growth, associated health problems for the occupants and the conditions for fungal decay and insect attack for traditional buildings. Meanwhile, a more recent paper by Bone et al. [52] emphasised a real need for large-scale longitudinal studies to assess the relationships between energy efficiency, ventilation, indoor air quality and health.

\section{HOLISTIC APPROACHES FOR SUSTAINABLE ENERGY EFFICIENCY IN REUSE OF HERITAGE BUILDINGS}

There are a number of other 'unknown quantities' involved in refurbishment projects, in particular when dealing with conversion projects such as churches, warehouses and other industrial buildings. Some of these complex refurbishment and adaptation projects can be problematic in terms of energy efficiency and may result into air tightness and heat loss problems, resulting in higher than expected

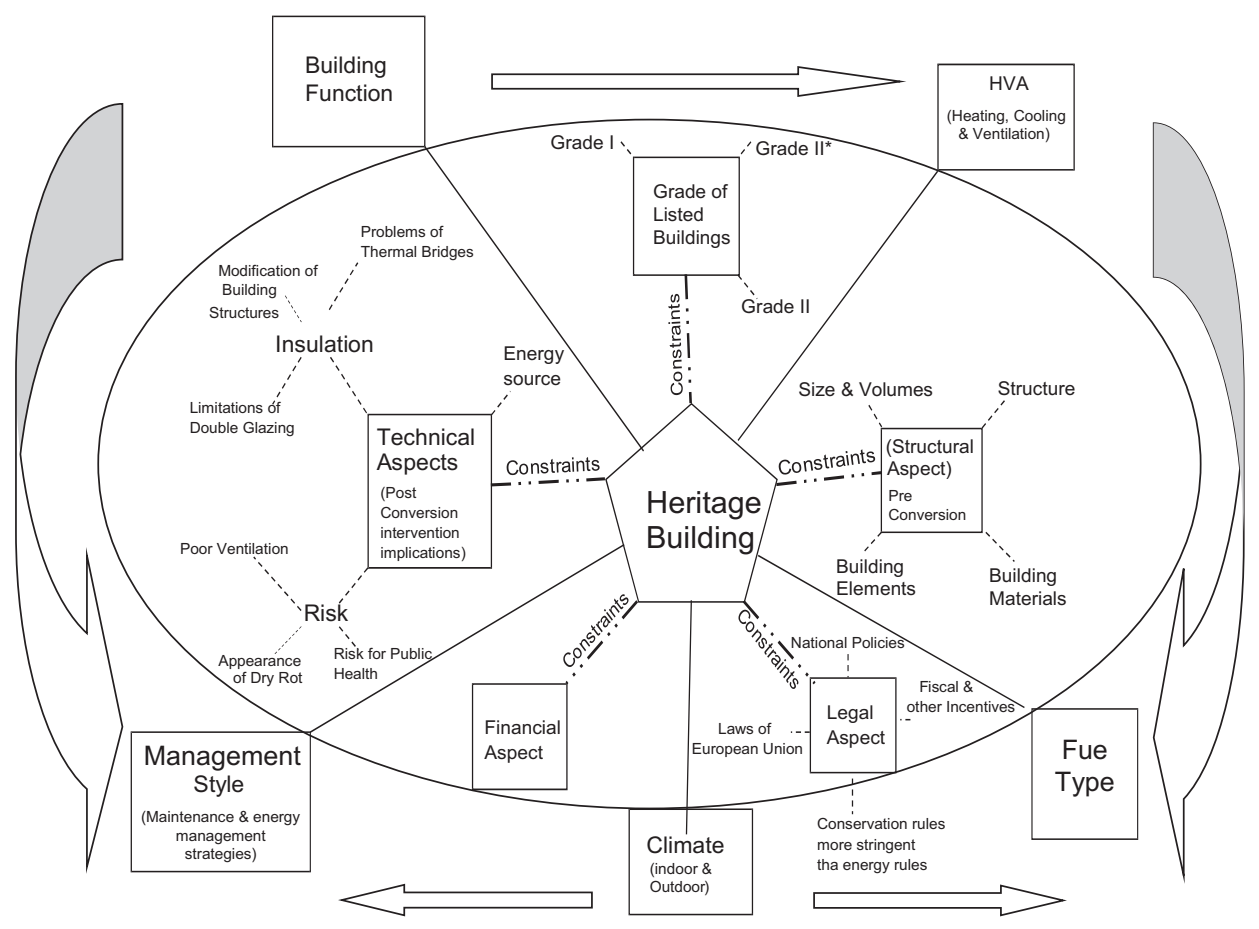

Figure 5: Framework for factors and possible consequences to consider when incorporating energy efficiency in reuse of heritage buildings. 
energy costs. These will require a holistic approach through some thorough surveys of the existing structures and consideration of other suitable and appropriate options through innovative techniques and application of different energy technologies.

These should be done in an integrated way, within and for a building, if technical and project management problems are not to result in over-runs in both time and budget. The holistic approach should consider many factors and their implications for the building when incorporating energy efficiency measures in conversion of heritage buildings. The factors as shown in Fig. 5 includes constraints of character of different grades of listed buildings, structural, technical, financial and legal aspect along with other characteristics such as:

- Predominant Climate of the area

- Management style (i.e. energy management strategies such as active and passive measures)

- Building function

- Fuel type

- Heating, cooling and ventilation system

- Identifying the building's total needs and options

- The building's inherent energy efficiency features

- The history of the building and energy use

- Possible unintended consequences of application of modern technologies

- The building's current situation, e.g. what works and what may be problematic

The key to long term sustainable refurbishment projects and improvement of energy efficiency of heritage buildings is in the identification, combinations and selection of the most appropriate energy efficient options for intervention for any particular building.

\section{CONCLUSION}

More efficient energy use in buildings continues to be one of the most untapped potential resources of value. The barriers and the constraints to accessing this untapped resource, especially in heritage buildings, are numerous and complex, but they can be overcome. To achieve this, it is important to draw valuable lessons from convincing real-world examples that demonstrate these possibilities. However, the stakeholders in the heritage industry will need to overcome their reservations about the compatibility of energy efficiency and building conservation. With relevant research, innovative ideas and approaches, along with flexible regulatory policies, energy efficiency improvement in heritage buildings can be achieved. In a world struggling to confront climate change, a holistic and synergistic approach for improving energy efficiency of all buildings must be a priority. Even though the regulation for buildings exempts most listed buildings from energy performance improvements, many of these buildings can and should be able to accommodate some improvements through options available for long term sustainability if the goal to reduce greenhouse gas emissions by $80 \%$ by 2050 is to be achieved.

\section{ACKNOWLEDGEMENTS}

The Department of Engineering and the Built Environment, Faculty of Science and Technology, Anglia Ruskin University, Chelmsford is gratefully acknowledged for supporting this ongoing research. A special acknowledgement is also made to Olivier Callebaut of Ir. Architecte - Partner and Steve Lowe of ThermalCities for their kind permission in granting the copyright to use the pictures in this article. 


\section{REFERENCES}

[1] Pew Center on Global Climate Change (PCGCC), Energy Efficiency Standards and Targets., 2010 http://www.pewclimate.org/what_s_being_done/in_the_states/efficiency_resource.cfm (accessed 2 May 2011).

[2] World Business Council for Sustainable Development (WBCSD), Energy efficiency in buildings: transforming the market. www.wbcsd.org/Plugins/DocSearch/details.asp?DocTypeId=25 (accessed 25 August 2011), 2009.

[3] Kelly, M.J., Energy efficiency, resilience to future climates and long-term sustainability: the role of the built environment. Phil. Trans. R. Soc. A, 368, pp. 1083-1089, 2010. doi: http:// dx.doi.org/10.1098/rsta.2009.0212

[4] Wilkinson, S.J. \& Reed, R.G., The business case for incorporating sustainability in office buildings: the adaptive re-use of existing buildings. 14th Annual Pacific Rim Real Estate Conference, Kuala Lumpur, Malaysia, 2008.

[5] Sweatman, P. \& Managan, K., Financing energy efficiency building retrofits: international policy and business model review and regulatory alternatives for Spain. [Online] Available at http://www.ukgbc.org/site/document/download/?document_id=979 (accessed 2 May 2011), 2010.

[6] Steemers, K., Towards a research agenda for adapting to climate change. Building Research \& Information, 31(3-4), pp. 291-301, 2003. doi: http://dx.doi.org/10.1080/0961321032000097692

[7] Larsson, N., Adapting to climate change in Canada. Building Research \& Information, 32(1), pp. 71-74, 2003. doi: http://dx.doi.org/10.1080/0961321032000148514

[8] Rousseau, D., Adapting to climate change: some observations. Building Research \& Information, 32(1), pp. 58-60, 2004. doi: http://dx.doi.org/10.1080/0961321032000148505

[9] Lowe, R.J., Lessons from climate change: a response to the commentaries. Building Research \& Information, 32(1), pp. 75-78, 2004. doi: http://dx.doi.org/10.1080/0961321032000153743

[10] Ball, R., Developers, regeneration and sustainability issues in the reuse of vacant buildings. Building Research \& Information, 27(3), pp. 140-148, 1999. doi: http://dx.doi.org/ $\underline{10.1080 / 096132199369480}$

[11] Latham, D., Creative Re-Use of Buildings, Donhead Publishing Ltd: Dorset, United Kingdom, 2000.

[12] Douglas, J., Building Adaptation. Butterworth-Heinemann: Woburn, United Kingdom, 2002.

[13] Kohler, N. \& Hassler, U., The building stock as a research object. Building Research \& Information, 30(4), pp. 226-236, 2002. doi: http://dx.doi.org/10.1080/09613210110102238

[14] Gregory, J., Rehabilitation-new ways for older housing, New South Wales Department of Housing, http://www/housing.nsw.gov.au/rehab.htm, 2004.

[15] Rovers, R., Existing buildings, a hidden resource, ready for mining, http://www.sustainbalebuilding.info, 2004.

[16] Wood, C. \& Oreszczyn, T., Building Regulations and Historic Buildings - Balancing the needs for energy conservation with those of building conservation: an Interim Guidance Note on the application of Part L. [Pamphlet], 2004.

[17] Jackson, M., Embodied energy and historic preservation: a needed reassessment. Journal of Preservation Technology, 36, p. 4, 2005.

[18] Pearce, D., The Social and Economic Value of Construction, The Construction Industry's Contribution to Sustainable Development London: nCRISPC, 2003.

[19] United Nations Environment Programme (UNEP), Sustainable building construction: facts and figures Industry and Environment. April - September 2003 [online] Available at http://www. uneptie.org/media/review/vol26no2-3/005-098.pdf (accessed 2 May 2011), 2003. 
[20] Cole, R.J. \& Kernan, P.C., Life-cycle energy use in office buildings. Building and Environment, 31(4), pp. 307-317, 1996. doi: http://dx.doi.org/10.1016/0360-1323(96)00017-0

[21] Ball, R.M., Re-use potential and vacant industrial premises: revisiting the regeneration issue in Stoke-on-Trent. Journal of Property Research, 19(2), pp. 93-110, 2002. doi: http://dx.doi. org/10.1080/09599910210125223

[22] Bullen, P.A., Adaptive reuse and sustainability of commercial buildings. Facilities, 25(1/2), pp. 20-31, 2007. doi: http://dx.doi.org/10.1108/02632770710716911

[23] Itard, L. \& Klunder, G., Comparing environmental impacts of renovated housing stock with new construction. Building Research \& Information, 35, pp. 252-267, 2007. doi: http://dx.doi. org/10.1080/09613210601068161

[24] Itard, L., Embodied and operational energy use of buildings. Conference Proceedings of CIB W115 Construction Material Stewardship: Lifecycle Design of Buildings, ed. E. Durmisevic, Systems and Materials Enschede: The Netherlands CIB, 2009.

[25] European Performance of Building Directive (EPBD), Directive 2002/91/EC of the European Parliament and the Council on the energy performance of buildings. Official Journal of the European Communities, (4.1.2003), 2003.

[26] European Performance of Building Directive (EPBD), EPBD Recast, [online] Available at http://www.eceee.org/buildings/EPBD_Recast/ (accessed 25 April 2011), 2010.

[27] New4Old Project, Technical guidelines for building designers [online] Available at: http:// www.new4old.eu/guidelines/4_Technical\%20Guidelines\%20For\%20Building\%20Designers. pdf (accessed 2 May 2011), 2009.

[28] Kikira, M. \& Gigliarelli, E., Energy efficiency in historic buildings, the case study of the National Theatre of Rhodes, Greece and of the Zena Castle, Italy. [Online] Available at http:// www. sechurba.eu/files/admin/SECHURBA\%20Interim\%20Report.pdf (accessed May 2011), 2010.

[29] ThermalCities, www.ThermalCities.com.

[30] Heritage Counts, English Heritage Counts. English Heritage: London. [Online] Available at http://www.hc.english-heritage.org.uk/content/pub/HC08_National_Acc.pdf (accessed 25 April 2011), 2008.

[31] Judson, P., Iyer-raniga, U., Wong, James P.C. \& Horne, R., Integrating built heritage and sustainable development: can assessment tools be used to understand the environmental performance of existing buildings with heritage significance? Facing the Challenges - Building the Capacity: FIG Congress 2010, Sydney, Australia, 2010.

[32] Cantacuzino, S., Re/Architecture: Old Buildings/New Uses, Thames and Hudson: London, 1989.

[33] Fisher, A., New Life in Old Buildings, Stuttgart \& Zurich: Verlag, 1992.

[34] Powell, K., Architecture Reborn. Converting Old Buildings for New Uses, Rizzoli International Publications, Inc.: New York, 1999.

[35] Douglas, J., Building Adaptation, 2nd edn., Elsevier: Oxford, 2006.

[36] Gorse, C. \& Highfield, D., Refurbishment and Upgrading of Buildings, Spon Press (Taylor and Francis): London \& New York, 2009.

[37] Boardman, B., Home Truths: A low carbon strategy to reduce UK housing emissions by 80\% Research Report for Co-operative Bank and Friends of the Earth, University of Oxford, 2007.

[38] English House Condition Survey (EHCS) Annual report 2007. Communities and Local Government: London, 2009.

[39] Meier, A., Wright, J. \& Rosenfeld, A.H., Supplying Energy through Greater Efficiency. The Potential for Conservation in California's Residential Sector, University of California Press: Berkeley, Los Angeles, London, 1983. 
[40] Lovins, A.B., Lovins, L.H., Krause, F. \& Bach, W., Least-Cost Energy: Solving the $\mathrm{CO}_{2}$ Problem, Andover, Mass: Brick House, 1989.

[41] Koomey, J., Akbari, H., Blumstein, C., Brown, M.A., Brown, R., Calwell, C., Carter, S., et al., Defining a standard metric for electricity savings. Environmental Research Letters, 5(1), p. 014017, 2010. doi: http://dx.doi.org/10.1088/1748-9326/5/1/014017

[42] Levine, M., Urge-Vorsatz, D., Blok, K., Geng, L., Harvey, D., Lang, S., Levermore, G., Mongameli Mehlwana, A., Mirasgedis, S., Novikova, A., Rilling, J. \& Yoshino, H., Residential and commercial buildings. In Climate Change 2007: Mitigation. Contribution of Working Group III to the Fourth Assessment Report of the Intergovernmental Panel on Climate Change, ed. B. Metz, O.R. Davidson, P.R. Bosch, R. Dave \& L.A. Meyer, Cambridge University Press: Cambridge, United Kingdom and New York, NY, USA, 2007.

[43] Zidar, M. \& Hrs Borković, Ž., Integrated approach to energy efficiency in cultural heritage buildings. Proc. of the Int. Conf. on energy management in cultural heritage. Available at http://www.an-patrimoine-echanges.org/IMG/pdf/session_s3_-_margareta_zidar_-_institut_ de_1_energie_-_zagreb_croatie.pdf, 2011.

[44] Godwin, P.J., Building conservation and sustainability in the United Kingdom. Procedia Engineering, 20(2011), pp. 12-21, 2011.

[45] Eco-refurbishment and the historic environment. www.bristol.gov.uk/ecohome.

[46] Oxley Conservation, Making older and historic buildings energy efficient. Available at http:// www.oxleyconservation.com/publications/documents/0611Makingolderandhistoricbuildingse nergyefficient.pdf, 2006.

[47] Hay, F.M., Re-use methodologies and design toolkit. Centre for the Recycling and Reuse of Buildings. Available at http://www.recyclingandreuseofbuildings.com/page12.htm, 2010.

[48] Sustainable Traditional Buildings Alliance (STBA), Responsible retrofit of traditional buildings. A report on existing research and guidance with recommendations. Available at http:// www.building.co.uk/Journals/2012/09/27/x/u/l/RESPONSIBLE-RETROFIt.pdf, 2012.

[49] English Heritage. Energy Efficiency and Historic Buildings: Draught-proofing windows and doors. Available at http://www.english-heritage.org.uk/publications/eehb-draught-proofing -windows-doors/eehb-draught-proofing-windows-doors.pdf, 2012.

[50] Andersson, A.C., Folgen zusätzlicher Wärmedämmung - Wärmebrucken, Feuchteprobleme, Wärmespannungen, Haltbarkeit. Bauphysik, 2(4), pp. 119-124, 1980.

[51] Schnieders, J., Innendämmung - Potenziale und Grenzen; Protokollband 32, Faktor 4 auch bei sensiblen Altbauten: Passivhauskomponenten + Innendämmung, 17-32 Passivhaus Institut, 2005 .

[52] Hopper, J., Littlewood, J., Geens, A., Karani, G., Counsell, J., Evans, N., et al., Assessing the execution of retrofitted external wall insulation for pre-1919 dwellings in Swansea (UK). Retrieved from University of Salford website: http://.www.salford.ac.uk/_data/assets/pdf_ file/0006/.../011-Hopper.pdf, 2012.

[53] Bone, A., Murray, V., Myers, I., Dengel, A. \& Crump. D., Will drivers for home energy efficiency harm occupant health? Perspectives in Public Health, 130(5), pp. 233-238, 2010. doi: http:// dx.doi.org/10.1177/1757913910369092 